\title{
Ecosystem-Based Adaptation to Protect Avian Species in Coastal Communities in the Greater Niagara Region, Canada
}

\author{
Samantha Gauthier ${ }^{1}$, Bradley May ${ }^{1}$ and Liette Vasseur ${ }^{1,2, * \mathbb{D}}$ \\ 1 Environmental Sustainability Research Centre, 1812 Sir Isaac Brock Way, St. Catharines, ON L2S 3A1, Canada; \\ sd_gauthier@hotmail.com or sg19kv@brocku.ca (S.G.); bmay@brocku.ca (B.M.) \\ 2 Department of Biological Sciences, UNESCO Chair in Community Sustainability: From Local to Global, \\ Brock University, 1812 Sir Isaac Brock Way, St. Catharines, ON L2S 3A1, Canada \\ * Correspondence: lvasseur@brocku.ca; Tel.: +905-688-5550 (ext. 4023)
}

check for updates

Citation: Gauthier, S.; May, B.;

Vasseur, L. Ecosystem-Based Adaptation to Protect Avian Species in Coastal Communities in the Greater Niagara Region, Canada. Climate 2021, 9, 91. https:/ /doi.org/ $10.3390 /$ cli9060091

Academic Editor: Chris Swanston

Received: 25 April 2021

Accepted: 3 June 2021

Published: 4 June 2021

Publisher's Note: MDPI stays neutral with regard to jurisdictional claims in published maps and institutional affiliations.

Copyright: (c) 2021 by the authors. Licensee MDPI, Basel, Switzerland. This article is an open access article distributed under the terms and conditions of the Creative Commons Attribution (CC BY) license (https:// creativecommons.org/licenses/by/ $4.0 /)$.

\begin{abstract}
Coastal communities are increasingly vulnerable to climate change and its effects may push coastal ecosystems to undergo irreversible changes. This is especially true for shorebirds with the loss of biodiversity and resource-rich habitats to rest, refuel, and breed. To protect these species, it is critical to conduct research related to nature-based Solutions $(\mathrm{NbS})$. Through a scoping review of scientific literature, this paper initially identified 85 articles with various ecosystem-based adaptation $(\mathrm{EbA})$ strategies that could help conserve shorebird populations and promote ecotourism. Of these 85 articles, 28 articles had EbA strategies that were examined, with some like coral reefs and mangroves eliminated as they were inappropriate for this region. The scoping review identified four major EbA strategies for the Greater Niagara Region with living shorelines and beach nourishment being the most suitable, especially when combined. These strategies were then evaluated against the eight core principles of nature-based solutions protecting shorebird as well as human wellbeing. Living shoreline strategy was the only one that met all eight $\mathrm{NbS}$ principles. As the coastline of the region greatly varies in substrate and development, further research will be needed to decide which $\mathrm{EbA}$ strategies would be appropriate for each specific area to ensure their efficacy.
\end{abstract}

Keywords: shorebirds; ecosystem-based adaptation; nature-based solutions; climate change; coastal; shorelines; biodiversity

\section{Introduction}

Human communities and wildlife located in the coastal zone are increasingly vulnerable to hazards and the impacts associated with climate change. Hazards-such as storm surges, ice storms, and heavy rainfall-increase water level fluctuations, which can lead to erosion and flooding [1,2]. In coastal communities, these multiple stressors may cause coastal ecosystems to undergo sudden, rapid, and irreversible changes [3]. This can result to habitat loss, land degradation, and the reduction or removal of species diversity as well as associated ecosystem functions and services [4,5]. Habitat loss is widely used as a measurement for the risk of extinction of species and is considered an important factor for the decline of shorebird populations [6]. The loss of these habitats results in a loss of resource rich habitats and an increase in shorebird population decline [7]. The long-term accumulation of impacts caused by climate change and loss of land are detrimental to the feeding and nesting ground generally available, resulting in a shift in many species' natural migration patterns. This accumulation of effects can cause a negative impact on population density and a shift in biodiversity $[1,2,6]$.

Several changes in the natural behavior of shorebirds have also been documentedsuch as altitudinal shifts [8], earlier breeding [5], timing of migration [8], breeding performance (egg size, nesting success) [5], and population distributions [9]. Due to the increased stressors of climate change and human intrusion, shorebirds are among the bird groups of highest conservation concern in the world with three times as many species declining as 
increasing [10]. Climate change is predicted to cause approximately $400-550$ bird species extinctions globally, and an additional 2150 species may be at risk of extinction by 2100 [11]. Most shorebirds must undertake energetically demanding migrations covering thousands of kilometers between breeding and non-breeding sites, and several species interrupt their journeys to rest and refuel at stopover sites along the way [12]. With the decline of many species, conservation is critical for maintaining healthy communities that consist of many diverse species as well as healthy ecosystems.

This study focuses on the Great Lakes, particularly the Greater Niagara Region, Ontario, Canada (Figure 1). Increasing occurrences of extreme weather events have led to greater water level variability and impacts on these coastal communities. There is a strong uncertainty regarding these changes, such as changes in ice conditions and wave actions, and further research is needed to identify potential effective adaptation strategies [13]. Due to the projected increase in extreme weather events due to climate change including stronger storms and high variability in water levels, the coastal areas of Niagara are facing increased erosion and flooding (e.g., flooding of 2017 and 2019) [14]. These events have had major impacts to the human communities as well as the shorebirds and their habitats. Focusing this study on the Greater Niagara Region is of importance as it is also a major support area for seasonal and migratory shorebirds [15].

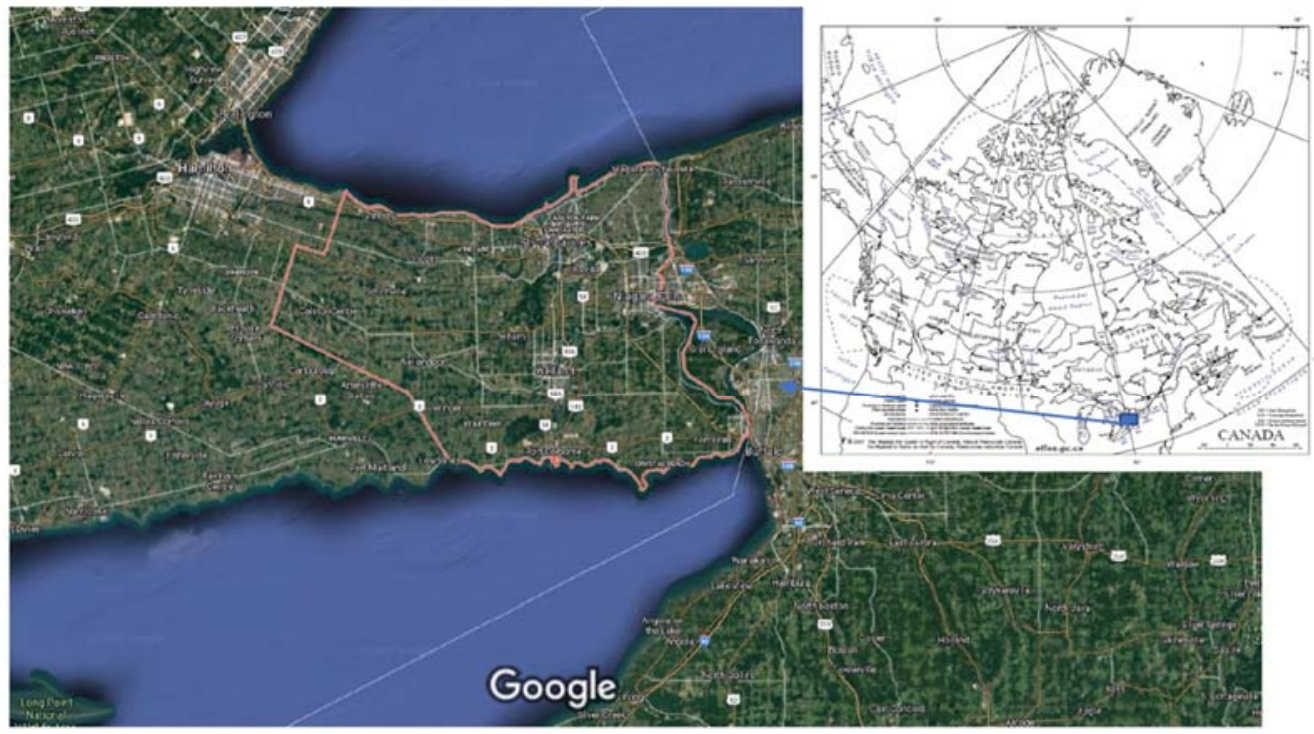

Imagery (C2021 TerraMetrics, Map data @2021 $10 \mathrm{~km}$

Figure 1. Map of the Niagara Region (Sources: map of Canada: Natural Resources Canada http:// open.canada.ca/en/open-government-licence-canada; Niagara Region: Google Earth 2021, accessed on 20 May 2021) (43.06001, -79.106667$)$.

The status of shorebirds is becoming a concern throughout coastal communities; thus, there is a need to determine which adaptation measures could be used to improve shorelines and increase shorebird protection, especially in the face of climate change, while supporting human communities. Nature-based solutions $(\mathrm{NbS})$ are a useful approach to addressing multiple societal challenges-including climate change, food, and water security, land degradation, and biodiversity loss [16]. NbS refers to the sustainable management and use of nature for addressing socio-environmental challenges [17]. The concept of NbS is an umbrella term that includes various strategies such as ecosystem approach, forest landscape restoration, ecological restoration, and ecosystem-based adaptation (EbA). Ecosystembased adaptation can be defined as any strategies or actions that promote the use of naturebased solutions to enhance the sustainability and the resilience of the social-ecological system [17]. EbA is a suitable approach to multiple social-ecological challenges such as the combination of coastal development, environmental protection, and climate change. To be 
successful, EbA needs to combine multiple stakeholders-including residents, municipal authorities, and conservation organizations-to ensure that adaptation strategies and solutions can be mainstreamed [17].

To be a NbS, any intervention should be evaluated according to eight core principles, which are now integrated as NbS Global Standard [18]. EbA is part of the series of NbS solutions that help social-ecological systems become more resilient by promoting biodiversity conservation and ecosystem services. This approach also relates to principles of community engagement and supports adaptive governance [18]. As EbA is a sub-category of the NbS, evaluating the NbS principles of each EbA strategy allows for identification of the effectiveness of each individual strategy and how they benefit social-ecological systems. Evaluating the $\mathrm{NbS}$ principles also assists with the initial planning of adaptation management as well as identifying which areas of each strategy need to be improved overall to be sustainable [19]. The purpose of the study was to examine how NbS, specifically EbA strategies, could be applied to protect the biodiversity of avian species in coastal communities with a focus on the Greater Niagara region while supporting human communities. Through a scoping review, the objectives were to identify potentially effective strategies to help reduce the impacts of climate change as well as determine their strengths and weaknesses according to $\mathrm{NbS}$ principles.

\section{Materials and Methods}

\subsection{Study Location}

The Niagara Region is an isthmus located in the southern part of the province of Ontario (43.06001, - 79.106667) (Figure 1). This region is located in Southern Ontario and located between two Great Lakes, Lake Ontario to the west and Lake Erie to the east. The climatic context of the region is considered a moderate continental climate with uniform precipitation throughout the year. Due to the region's location and climatic atmosphere the Greater Niagara Region is well known for agriculture and tourism. These two sectors make up the main economic development of the region. The Niagara region's location between two Great Lakes making it an ideal corridor for migrating birds. This region is home to six sites that are designated as Important Bird Areas (IBA). IBAs aim to increase awareness among governments and conservation practitioners on the importance of bird habitats worldwide and are identified using a systematic selection process based on populations of species occurring in a defined area at certain population thresholds. The species may trigger one or more of the following criteria: globally threatened species, range-restricted species, biome-restricted species, and congregation [20]. All the IBAs in the Greater Niagara Region either extend over water or lie adjacent to water, which demonstrates the importance of lakes, rivers, and creeks for the breeding of migratory birds in Niagara [15].

The region has been affected by climate change, like the rest of the Great Lakes, with an increase of $1{ }^{\circ} \mathrm{C}$ between $1901-2016,19$ warmest years on record since 2000 with $1.02{ }^{\circ} \mathrm{C}$ warmer average, $13.6 \%$ increase in precipitation since 1951, and an increase of 16 frost free days since 1951 [21]. It is projected that there will be an increase in hot days over $30^{\circ} \mathrm{C}$, heat waves and droughts, number of winter freeze-thaw cycles, precipitation with most of the increase in winter as rain, and heavy rainfall events, especially in the spring [22,23]. These projections also bring issues of move wave actions in the winter and rainfall runoff along the coast in the spring leading to increases erosion, especially in area with high slopes and/or sandy shores like in Charles Daley Park.

\subsection{Scoping Review Process}

The project used a two-phase approach to perform a scoping review. During phase one of this approach, a scoping review was performed by following the PRISMA-ScR (Preferred Reporting Items for Systematic Reviews and Meta-Analyses extension for Scoping Reviews) checklist [24]. The search terms were as follows: shore or coast AND birds AND climate change or ecosystem-based adaptation. A complete screening process was performed using inclusion and exclusion factors listed in Table 1. From an initial 3408 articles identified, 
following exclusion factors, 85 articles were used for this scoping review, the full review process can be seen as a flow chart in Figure 2.

Table 1. Inclusion and exclusion categories used for deciding the final list of articles for the scoping review. This table was adapted from the PRISMA-ScR guidelines [24].

\begin{tabular}{llll}
\hline \multicolumn{1}{c}{ Inclusion Factor } & \multicolumn{1}{c}{ Exclusion Factor (Not Related to EbA) } \\
\hline- & Climate change and SLR & Policies, law and decision making \\
- & $\begin{array}{l}\text { Ecosystem-based adaptation strategy } \\
\text { evaluations }\end{array}$ & - & Geographical location (mountains, urban \\
spaces, grasslands) & Coastal Risk Assessment/Vulnerability \\
- & $\begin{array}{l}\text { Ecosystem-based adaptation strategies in } \\
\text { coastal communities }\end{array}$ & - & Assessments \\
- & Grey infrastructure & - & Water resource management and quality \\
- & Integrated Coastal Zone Management & - & Wind energy \\
- & Ecotourism & - & Global temperature rising and $\mathrm{CO}_{2}$ levels \\
- & Biodiversity and climate change & - & Food webs \\
- & Shorebird declines & - & Public health \\
- & Nature-based Solution evaluations & - & Evolution of morphology \\
&
\end{tabular}

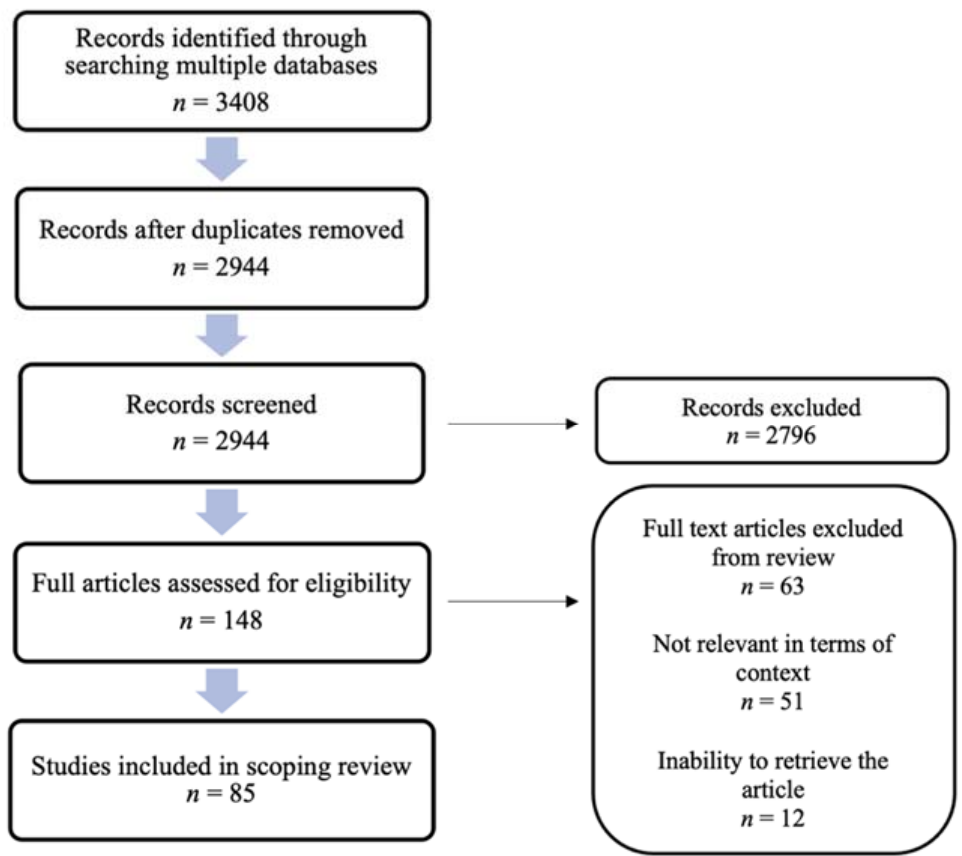

Figure 2. Flow diagram illustrating the selection literature sources used in the scoping review process. This flow diagram was adapted from the PRISMA-ScR guidelines [24]. 
Table 2. Nature-based solution principles used in evaluation of Ecosystem-based adaptation strategies. Source of the NbS core principles: Cohen-Shacham et al. [19] (pp. 25).

\begin{tabular}{|c|c|}
\hline \multicolumn{2}{|r|}{ Nature-Based Solution (NbS) Principles } \\
\hline Principle 1 & NbS embrace nature conservation norms (and principles) \\
\hline Principle 2 & $\begin{array}{l}\text { NbS can be implemented alone or in an integrated manner with other } \\
\text { solutions to societal challenges (e.g., technological and engineering solutions) }\end{array}$ \\
\hline Principle 3 & $\begin{array}{l}\mathrm{NbS} \text { are determined by site-specific natural and cultural contexts that include } \\
\text { traditional, local and scientific knowledge. }\end{array}$ \\
\hline Principle 4 & $\begin{array}{l}\text { NbS produce societal benefits in a fair and equitable way in a manner that } \\
\text { promotes transparency and broad participation. }\end{array}$ \\
\hline Principle 5 & $\begin{array}{l}\mathrm{NbS} \text { maintain biological and cultural diversity and the ability of ecosystems to } \\
\text { evolve over time. }\end{array}$ \\
\hline Principle 6 & $\mathrm{NbS}$ are applied at a landscape scale. \\
\hline Principle 7 & $\begin{array}{l}\mathrm{NbS} \text { recognize and address the trade-offs between the production of a few } \\
\text { immediate economic benefits for development, and future options for the } \\
\text { production of the full range of ecosystem services. }\end{array}$ \\
\hline Principle 8 & $\begin{array}{l}\text { NbS are an integral part of the overall design of policies, and measures or } \\
\text { actions, to address a specific challenge. }\end{array}$ \\
\hline
\end{tabular}

\section{Results}

\subsection{Scoping Review Analysis}

All 85 articles initially reviewed took place in coastal communities in all continents, except Antarctica. Nineteen articles (22\%) were not specific to any geographical zone and addressed adaptation strategies from a global context and were omitted for the analysis on $\mathrm{EbA}$ and $\mathrm{NbS}$ principles. The complete range of articles geographically was from South America (3.5\%), Africa (6\%), Oceania (8.5\%), Asia (9\%), Europe (25\%), and North America (26\%). The years of publications of the 85 articles ranged from 1997 to 2020 (Figure 3). Over 55\% (47 out of 85 ) of the articles were published in the last 5 years, i.e., between 2016 and early 2020, and almost $86 \%$ of the articles in the last 10 years (between 2011 and early 2020). With the remaining 14\% of articles published between 1997 and 2010, this reflects the growing importance of climate change adaptation as a climate action for the coastal communities globally and its relevance for the future.

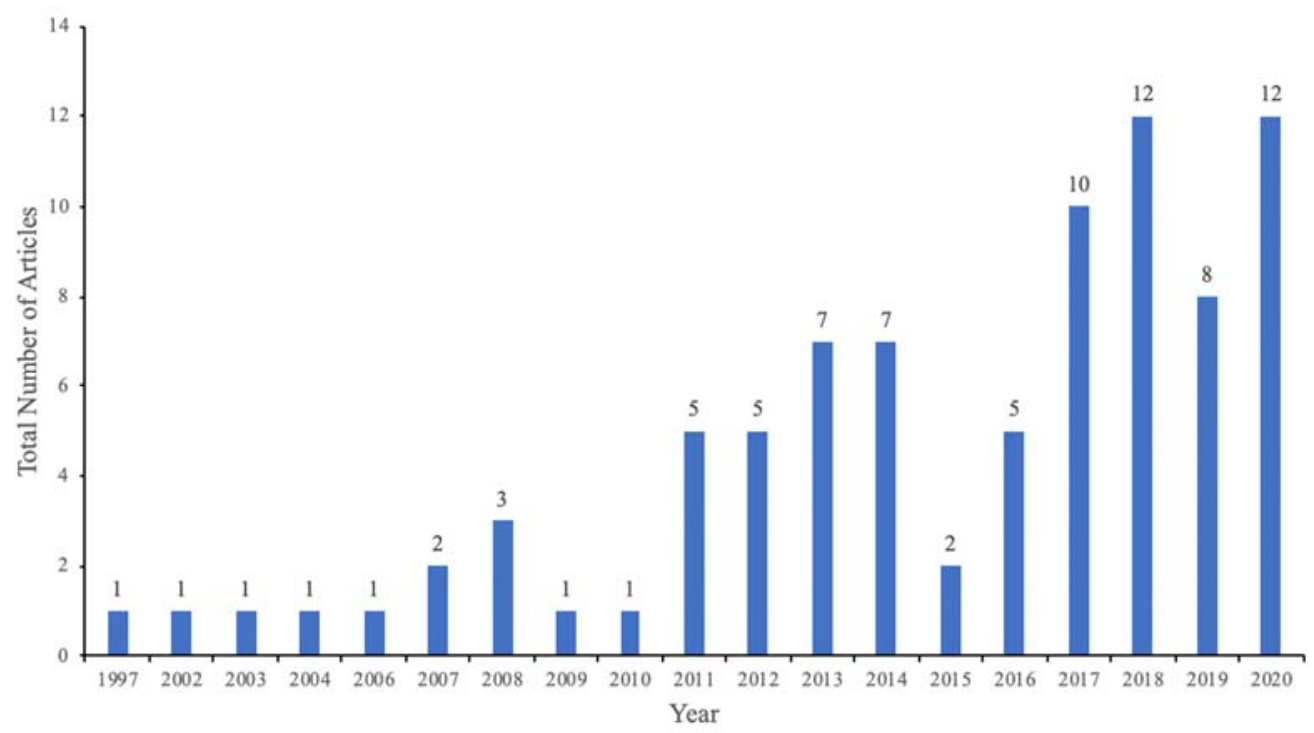

Figure 3. Years of publication of the 85 articles included in the scoping review of coastal adaptation to climate change using Ecosystem-based Adaptation strategies.

Of the 85 articles, 22 articles directly addressed shorebird conservation and protection or restoration of their habitat. These articles focused on several cases studies and reviews 
looking at how climate change is affecting the populations and biodiversity of a variety of shorebird species. Thirty-five articles were used for relevant background knowledge on how to properly evaluate $\mathrm{EbA}$ and $\mathrm{NbS}$ strategies therefor these papers were not referenced in the text. Of the remaining 85 articles a total of 28 articles were extracted for the evaluation of EbA strategies, some of which discussed multiple EbA strategies. Note that 6 articles on coral reefs and 12 articles on mangroves were immediately excluded as they were not appropriate in terms of climatic conditions for the region. By the end, four EbA strategies were identified as promising and potential feasible for the Niagara region: forest cover, living shores, managed retreat and realignment, and beach nourishment. The remainder of the analysis thus consisted of 6 articles used for forest cover, 12 articles for living shorelines, 6 articles for managed retreat and realignment, and 9 articles for beach nourishment.

\subsection{Ecosystem-Based Adaptation Strategies}

The strategies and methods used in this scoping review led us to the results of four major groups of EbA strategies that were identified as potentially interesting and feasible for the Niagara Region: forest cover, living shorelines, managed retreat and realignment, and beach nourishment.

The first potential strategy was forest cover, which can be described as heavy forested areas to provide canopy cover and a barrier against weather events [25]. Forested area has been commonly used in riparian zones and along rivers in some areas of Canada to reduce flooding from ice melt $[25,26]$. This strategy was shown to be a beneficial option due to its ability to trap water, which reduces runoff rate and erosion, provides water filtration, increases habitat diversity, and can enhance tourism and recreation [18,25,27-29]. While the result showed many benefits to this strategy, it also revealed some challenges such as having extensive national regulations for buffer properties, often being heavily affected negatively by increasing population density, and potential tree falls that may affect resilience of shorelines [25,28-30]. The most interesting case studies include the use of forest cover along rivers to reduce flooding when a community experiences flooding due to ice jam [25] and the use for coastal and agricultural lands in India with highly populated areas to reduce impacts on humans as well as creating wildlife habitats [18].

Managed realignment and retreat represented the second EbA strategy showing promises as a sustainable strategy in many areas such as low development areas, beaches, and riparian areas $[27,31]$. Managed retreat or realignment is the partial or total removal of man-made or hard infrastructure strategies. This strategy was shown to be a beneficial option due to its ability to create or improve natural habitat, allow natural sand transport and is economically more feasible than continued defense [31-33]. It has been used to retore salt marshes, thus reducing exposure of humans to storms and increasing potential shorebird habitats [31]. This strategy was beneficial in low impact conditions where wave attenuation might not be as high and these realigned habitats, such as salt marshes, creating important biodiversity benefits for many shorebird species [31]. However, this option may not always be feasible especially in areas that are highly developed due to the difficulty of realigning or retreating heavy populations and dense concentrations of infrastructure [3]. It also presents challenges regarding proper disposal of previous defense infrastructures or buildings and can be a costly strategy to achieve or maintain [32,33]. For example, this strategy has been used in Norfolk, UK, to restore salt marshes [34] or in New York, USA, to increase piping plover habitats [35].

The third option was living shorelines. This EbA involves the restoration, enhancement or protection of ecosystems, such as marshes and coastal grasslands, which provide feeding ground for many migrating shorebirds due to greater vegetated habitats, while protecting human populations at the same time [36]. Living shorelines are categorized as a larger group of green infrastructure practices, which include a greater range of nature-based techniques for inland areas that address a variety of issues in place of hard infrastructure. This strategy was shown to be a beneficial option due to its potential to address erosion through restoration and protection, enhance existing habitats or create new natural 
habitats, reduce wave height and strength as well as sediment retention through root systems $[3,18,34,36,37]$. However, challenges arise if there is a lack of proper planning on incorporating these strategies as success depends on vegetation characteristics, design, and setting of the area [37-39]. Such an EbA has been proven to be more effective in North Carolina than grey infrastructure and more cost-efficient [38].

The fourth option was beach nourishment. Beach nourishment is the process of adding sand onto eroding beaches. Sand is brought in from offshore and pumped onto eroding beaches or brought from other location. It helps restore beaches while also protecting shoreline structures from erosion, wave action, and storm forces. This strategy was shown to be beneficial due to its potential to enhance natural processes and biodiversity, contribute to beach recreation and tourism, act as a buffer between water and land and was recorded to be the most promising long-term solution compared to alternative strategies [40-43]. This strategy also has challenges such as requiring constant maintenance, monitoring, and modeling, needing regular nourishment after storms and can have negative impacts on groundwater [43-45]. Beach nourishment has been done in several locations around the world where tourism is important; however, it has also been done in Georgia to provide more nesting habitat, attracting foraging activities, and reducing next predation [36]. In the example of Dollard coast of the Wadden Sea, a wide green dike pilot program was implemented as a flood protection system [43].

\subsection{Analysis of Ecosystem-Based Adaptation Strategies with Nature-Based Solution Principles}

The four EbA strategies were then assessed against the eight core NbS principles set out by Cohen-Shacham et al. [19] (pp. 25). The interpretation and implementation of the $\mathrm{NbS}$ concept is very context specific, depending on a variety of factors influencing the societal challenges being addressed. This being the case, it is only feasible to standardize the processes for the design and execution of NbS each time a solution is implemented [16]. For this individual study, each strategy was evaluated on a coastal ecosystem setting and overall, the strategies identified by the scoping review met on average 5.5 of the $\mathrm{NbS}$ principles.

Through evaluation of the case studies against the standards of NbS only living shorelines met all the eight core principles. This was mainly because the case studies showed that while it deals with societal challenges such as higher energy sites (Principle 2) [38], it helps promote nature conservation through the planting of vegetation and habitat formation for many species (Principle 1) [26,38]. It can integrate cultural aspects, bring societal benefits, and enhance biodiversity by both benefitting both natural environments as well as economic environments (Principles 3,4,5) [3,26,38]. Because of the capacity to be at a larger scale than the other EbA strategies, it can be applied at the landscape level (Principle 6) [26]. Case studies showed that trade-offs were possible ad thus integrated into policies at the local and regional levels (Principles 7, 8) [3,38].

According to the case studies examined, the forest cover strategy cover Principles 1 and 5 through the promotion of nature and biodiversity conservation by planting trees which create habitat and restore habitat for many species [28,36]. This strategy meets Principle 2 as it can either be implemented alone or as an integrated method with other green strategies [27]. Principles 4 and 6 were also met in this strategy through its capacity to be implemented at a larger landscape level scale as well as providing both environmental and economic benefits by creating buffers to protect human infrastructure and communities [28,36]. None of the articles mentioned the possibility of trade-offs regarding ecosystem services as it is mainly to maintain forested areas and the possibility to be integrated into overall policies to address specific challenges.

Beach nourishment met a total of five NbS principles. Through the widening of beaches on a landscape scale it promotes the enhancement of natural habitats coastal fauna and flora, this can also be used in combination with living shorelines for increased productivity (Principle 1, 2,6) $[34,36]$. The planning and implementation of this strategy 
involves multiple stakeholders and provides benefits for both environmental and economic areas allowing for broad participation at all levels (Principles 4, 8) [34,46].

The strategy that met the least number of principles, only four principles, was managed retreat and managed realignment. Managed realignment and retreat allow for natural coastal erosion, sand transport, and reduce impact of storms at a landscape scale which allows for conservation of these areas (Principles 1, 6) [27,31]. This method is often used in combination with beach nourishment in order to complete the process of retreat (Principle 2) [31,36]. This strategy also recognizes and addresses the trade-offs between the production of a few immediate economic benefits for development through the promotion of tourism and protection of human infrastructure (Principle 7) [27].

\section{Discussion}

The Greater Niagara Region is affected by climate change, especially increase in water level variability and frequency of extreme weather events. In the recent years, most likely due to the 2017 and 2019 flooding and storm damage, coastal communities are increasingly concerned. While water levels in the Great Lakes have been historically highly variable, climate change is projected to lead to an increase in this variability. This uncertainty is affecting many factors, including ice conditions and wave actions [35]. These combined uncertainties related to water level fluctuations can have dramatic effects on coastal communities such as land degradation and can affect associated ecosystem functions and services [4]. The coastlines of the 12 municipalities of the Greater Niagara Region vary significantly from place to place in terms of geology, topography, and habitats [15]. For this reason, some strategies may be more suitable for some areas than for others.

In this study, we focused on the EbA strategies of the coastline that can promote the protection of shorebirds such as the bank swallow, which is in significant decline in the region $[15,44,47]$. Focusing this study on the conservation of shorebirds is especially important in the Niagara Region as it is a major support area for seasonal and migratory shorebirds and represents an interesting ecotourism industry [15]. Habitat protection is vital for shorebird populations adaptation to climate change. EbA is therefore a sustainable adaptation strategy. The results of this scoping review showed that four broad adaptation strategies were potentially the most efficient for this region: forested areas, managed realignment and retreat, living shorelines, and beach nourishment. Among these four, according to $\mathrm{NbS}$, living shorelines would be the most promising EbA strategy for the Niagara Region.

The case studies from this scoping review suggested that several EbA strategies could be used in combination to be potentially beneficial in the coastal communities of the Greater Niagara Region. However, it is important to mention that while peer reviewed articles make up most of this research, grey literature also has a lot to offer and can provide great examples for how EbA strategies can be used in Niagara. For example, forest cover has been shown to provide beneficial habitat for many shorebird species but is best used low-lying areas around lakes and in riparian zones [28,29]. The only case study done in Canada shows that forest cover along rivers helps reduce flooding from the increased water levels due to melting ice during the spring months [18]. Due to Niagara's winter climate and the Niagara river running through the Greater Niagara Region using forest cover on riparian areas would be beneficial in reducing the impacts from water level fluctuations and flooding [22]. Forest cover also provides habitat and helps moderate both spring floods and summer droughts according to the Niagara Peninsula Conservation Authority (NPCA) [48]. In combination with other methods such as managed retreat or living shorelines this strategy has potential to be beneficial for other coastal regions of the Greater Niagara Region [16].

Another strategy potentially beneficial in some locations along the coastline is managed realignment or retreat. A case study performed in New Jersey reports that managed retreat of the coastal zone increases the area for piping plovers to nest and rest during migration [44]. While this strategy can prove beneficial in some areas, it may become difficult 
to implement in areas of heavy human development. In areas that have lower levels of development this strategy may prove as beneficial. The University of waterloo conducted studies in Ontario where managed retreat and realignment would be most beneficial and a case study showed that residential properties and infrastructure surrounding Lake Erie would be appropriate areas for this adaptation strategy [49]. Lake Erie is unique as it is a series of cases along a $70 \mathrm{~km}$ stretch of Lake Erie which is experiencing severe flooding and erosion due to increased lake levels. Many shoreline communities are threatened under future climate change scenarios. Prime examples of retreat in this case would be residents being bought out through home buyouts and or roads being realigned due to concerns about erosion, this being the most cost-effective solution for the area [49]. A similar study in Chatham-Kent showed that beach nourishment alone was not enough to protect coastal communities and that retreat was the only option [14]. However, certain residential developments and tourist attractions are located too close to the coastlines in the Niagara Region, making this strategy more difficult to implement and at times entirely infeasible. For example, Clifton Hill in Niagara Falls is a major tourist center and heavily developed, this strategy would not be possible in such a developed area.

The two strategies that appeared to be most feasible in the Greater Niagara Region when used in combination were living shorelines and beach nourishment. Living shorelines provide an analogous solution to mangroves as these provide similar benefits and can be customized to individual areas in the Greater Niagara Region $[23,36]$. Living shoreline strategies such as salt marshes and coastal grasslands provide habitat and feeding ground for many migrating shorebirds [37,40]. A case study done in Jersey Shore [36] indicates that beach and dune construction can increase habitat for shorebirds, which may be beneficial for many of the surrounding beaches in the Niagara Region (e.g., the dunes in Fort Erie). New York has also taken initiative to implement living shorelines along the Niagara River. The Buffalo Niagara Waterkeeper's Living Shorelines program in New York is helping restore a more natural transition from lake to land in hardened and vulnerable areas [14]. These case studies show that both of these strategies also work well in hybrid situations where a combination of both grey and green infrastructure is required. There is a limitation to this combination as the term living shorelines include a variety of strategies (grasslands, vegetation). Future research would be needed to identify which particular living shoreline strategies provide the most benefits, and if these strategies should be used alone or in combination with each other in this studied region.

Only living shorelines met all of the eight core principles, which provided further evidence as to why this strategy might be most beneficial for the Greater Niagara Region. Even though beach nourishment only met five of the eight $\mathrm{NbS}$ core principles, in combination with living shorelines, it could provide a full spectrum of the principles. As many of these strategies did not meet the core NbS principles, EbA strategies might require improvements to enhance sustainability in the future and to be considered a $\mathrm{NbS}$ according to the Global Standard [19]. This research shows there is need for improvement when implementing EbA and NbS strategies. There is a need for more consultation in Niagara as there is lots of discussion but very little engagement. For example, both $\mathrm{NbS}$ Principles 3 and 8 need improvement. NbS 3 is determined by site-specific natural and cultural contexts that include traditional, local, and scientific knowledge. There is a need to ensure that all stakeholders are involved, and this will include Indigenous peoples as well as marginalized people who may be impacted by these strategies or others that can be implemented. Decisions are often based solely on science which may omit local and cultural knowledge. NbS 8 is an integral part of the overall design of policies, and measures or actions, to address a specific challenge. In order to improve this proactive there is a three-step process that can be recommended. This includes proper communication, proper governance, and proper implementation of the process of adaptation [49].

This scoping review examined strategies that could be implemented in order to achieve a more sustainable future in coastline areas of Niagara for both human population and wildlife. Due to the large population of shorebirds found near the Niagara River, it is 
considered an important tourism attraction for bird watching. Ecotourism through bird watching allows coastal communities to improve their economic status while obtaining support for conservation of their natural areas [32]. This study has the potential to contribute at assessing how EbA strategies can benefit IBA's in the Greater Niagara Region. These EbA strategies can help sustain IBA's through conservation of existing areas and restoration of areas at risk. Through the use of sustainable adaptation strategies, it has the potential to increase shorebird populations and biodiversity in Niagara's IBAs. Future research can be done to determine which strategy would be beneficial for each specific IBA and what benefits each strategy can bring to the shorebird ecosystem and biodiversity of each IBA.

There are currently many international, national, and local water governance mechanisms in the Great Lakes Basin that relate to the action possible in the Niagara Region. For example, the Great Lakes St. Lawrence Water Board's Adaptative Management Committee is committed to the identification and management of coping zones for the mitigation of flood and shoreline erosion risk [15,35]. The Great Lakes and St Lawrence Cities Initiative (an organization of the mayors of over 100 cities in the basin) has established a Resilience Advisory Council to identify and develop adaptation strategies and toolkits that can be adopted by these cities and NbS have been discussed in this matter [37]. Various Niagara Region municipalities are also developing climate change adaptation plans that incorporate best practices for natural infrastructure, ecosystem-based adaptation, and low impact development. This is the case for the Town of Lincoln where options are being contemplated for the protection of the shoreline, with unfortunately little mention of EbA (https://speakuplincoln.ca/climate-adaptation-plan, accessed 22 May 2021). Encouraging sustainable approaches to the coastal communities of the Niagara region can benefit the economy as Niagara is a large tourist community and in the year 2000, Ontario brough in 20 billion dollars in tourism alone [23].

Funding is also required and through collaboration from a variety of sectors, both public and private, and governments may help reduce the short-term financial burden of adaptation [18]. However, $\mathrm{NbS}$ and EbA strategies may lead to some challenges regarding governance, unless a true participatory approach is used. For EbA and NbS to be successful, governance requires active cooperation and coordination among all stakeholders at all levels [18]. Measuring the effectiveness of these strategies also appears to be a major barrier. While the Global Standard exists, assessing the effectiveness of $\mathrm{NbS}$ remains a challenge [18]. Effectiveness can be hard to determine due to the many different scales that $\mathrm{NbS}$ and $\mathrm{EbA}$ strategies are involved in, the level of efficiency could vary among the different scales involved. As NbS is a recent approach, the long-term success of both EbA and $\mathrm{NbS}$ has yet to be assessed [34].

\section{Conclusions}

Using a scoping review, this research analyzed four different EbA strategies that could be relevant for the coastal communities of the Niagara Region. These adaptation strategies were evaluated based on which $\mathrm{NbS}$ principles were met and the pros and cons of all the relevant adaptation strategies for the Niagara Region were also presented. These strategies were also evaluated based on social, economic, and environmental benefits for the area. It was determined that the most efficient strategies for the Greater Niagara Region were a combination of living shorelines and beach nourishment. Forest cover and managed realignment/retreat would also be beneficial in some areas, depending on geographical location and characteristics.

This research was performed to assess various NbS adaptation strategies, specifically $\mathrm{EbA}$ strategies, that would be beneficial for the coastal communities of the Greater Niagara Region in order to protect and conserve the biodiversity of avian species. The process involved analyzing the multiple strategies and comparing case studies to identify the most efficient strategies for the area. Due to the projected increase in climatic events from climate change such as stronger storms and rising water levels the coastal areas of Niagara 
are facing impacts such as erosion and flooding, this causes detrimental effects to the communities and the shorebirds in these areas. Future research is required to determine how to maximize the integration of $\mathrm{NbS}$ principles into these EbA strategies and policy considerations have also been suggested for the future that can build upon the findings of this research.

Author Contributions: Conceptualization, S.G. and L.V.; Methodology and formal analysis, S.G. and B.M.; Resources, L.V.; Writing-original draft preparation, S.G.; Writing-review and editing, S.G., L.V., and B.M.; Supervision, L.V. and B.M.; Project administration, L.V. and B.M.; Funding acquisition, L.V. All authors have read and agreed to the published version of the manuscript.

Funding: This work was supported by the Marine Environmental Observation, Prediction and Response (MEOPAR) Network [1-02-02-035.4].

Institutional Review Board Statement: Not applicable.

Informed Consent Statement: Not applicable.

Data Availability Statement: Not applicable.

Acknowledgments: The authors thank the Town of Lincoln for its logistical support.

Conflicts of Interest: The authors declare no conflict of interest.

\section{References}

1. Galbraith, H.; Jones, R.; Park, R.; Clough, J.; Herrod-Julius, S.; Harrington, B.; Page, G. Global Climate Change and Sea Level Rise: Potential Losses of Intertidal Habitat for Shorebirds. Waterbirds 2002, 25, 173-183. [CrossRef]

2. Thrush, S.F.; Halliday, J.; Hewitt, J.E.; Lohrer, A.M. The Effects of Habitat Loss, Fragmentation, and Community Homogenization on Resilience in Estuaries. Ecol. Appl. 2008, 18, 12-21. [CrossRef] [PubMed]

3. Powell, E.J.; Tyrrell, M.C.; Milliken, A.; Tirpak, J.M.; Staudinger, M.D. A Review of Coastal Management Approaches to Support the Integration of Ecological and Human Community Planning for Climate Change. J. Coast. Conserv. 2019, 23, 1-18. [CrossRef]

4. Allen, C.D.; Birkeland, C.; Chapin, F.S. Thresholds of Climate Change in Ecosystems: Final Report, Synthesis and Assessment Product 4.2; Publication of the US Geological Survey: Lincoln, Nebraska, 2009.

5. Sparks, T.; Crick, H.; Elkins, N.; Moss, R.; Moss, S.; Mylne, K. Birds, Weather and Climate. Weather 2002, 57, 399-410. [CrossRef]

6. Iwamura, T.; Possingham, H.P.; Chadès, I.; Minton, C.; Murray, N.J.; Rogers, D.I.; Treml, E.A.; Fuller, R.A. Migratory Connectivity Magnifies the Consequences of Habitat Loss from Sea-Level Rise for Shorebird Populations. Proc. R. Soc. B Biol. Sci. 2013, 280. [CrossRef]

7. Peterson, M.S.; Lowe, M.R. Implications of Cumulative Impacts to Estuarine and Marine Habitat Quality for Fish and Invertebrate Resources. Rev. Fish. Sci. 2009, 17, 505-523. [CrossRef]

8. Sims, S.A.; Seavey, J.R.; Curtin, C.G. Room to Move? Threatened Shorebird Habitat in the Path of Sea Level Rise-Dynamic Beaches, Multiple Users, and Mixed Ownership: A Case Study from Rhode Island, USA. J. Coast. Conserv. 2013, 17, 339-350. [CrossRef]

9. Crick, H.Q.P. The Impact of Climate Change on Birds: Impact of Climate Change on Birds. Ibis 2004, 146, 48-56. [CrossRef]

10. Watts, B.D.; Turrin, C. Assessing Hunting Policies for Migratory Shorebirds throughout the Western Hemisphere. Wader Study 2016, 123. [CrossRef]

11. Sekercioglu, C.H.; Schneider, S.H.; Fay, J.P.; Loarie, S.R. Climate Change, Elevational Range Shifts, and Bird Extinctions: Elevation, Climate Change, and Bird Extinctions. Conserv. Biol. 2008, 22, 140-150. [CrossRef]

12. Baker, A.J.; González, P.M.; Piersma, T.; Niles, L.J.; de Lima Serrano do Nascimento, I.; Atkinson, P.W.; Clark, N.A.; Minton, C.D.T.; Peck, M.K.; Aarts, G. Rapid Population Decline in Red Knots: Fitness Consequences of Decreased Refuelling Rates and Late Arrival in Delaware Bay. Proc. R. Soc. Lond. B Biol. Sci. 2004, 271, 875-882. [CrossRef]

13. Gronewold, A.D.; Stow, C.A. Water Loss from the Great Lakes. Science 2014, 343, 1084-1085. [CrossRef]

14. International Joint Commission. Short-Term and Long-Term Strategy For Evaluating and Improving the Rules for Managing Releases from Lakes Ontario and Superior. 2020. Available online: https://ijc.org/sites/default/files/2020-10/ GLAMShortAndLongTermStrategy-20200901-EN.pdf (accessed on 19 November 2020).

15. Black, J.; Roy, K. Niagara Birds: A Compendium of Articles and Species Accounts of the Birds of the Niagara Region in Ontario; Brock University: St. CatharineS, ON, Canada, 2010.

16. Seddon, N.; Chausson, A.; Berry, P.; Girardin, C.A.J.; Smith, A.; Turner, B. Understanding the Value and Limits of Nature-Based Solutions to Climate Change and Other Global Challenges. Philos. Trans. R. Soc. B Biol. Sci. 2020, 375, 1-12. [CrossRef]

17. Vasseur, L. How Ecosystem-Based Adaptation to Climate Change Can Help Coastal Communities through a Participatory Approach. Sustainability 2021, 13, 2344. [CrossRef] 
18. International Union for Conservation of Nature (IUCN). Guidance for Using the IUCN Global Standard for Nature-Based Solutions, 1st ed.; International Union for Conservation of Nature (IUCN): Gland, Switzerland, 2020.

19. Cohen-Shacham, E.; Andrade, A.; Dalton, J.; Dudley, N.; Jones, M.; Kumar, C.; Maginnis, S.; Maynard, S.; Nelson, C.R.; Renaud, F.G.; et al. Core Principles for Successfully Implementing and Upscaling Nature-Based Solutions. Environ. Sci. Policy 2019, 98, 20-29. [CrossRef]

20. Steven, R.; Morrison, C.; Arthur, J.M.; Castley, J.G. Avitourism and Australian Important Bird and Biodiversity Areas. PLoS ONE 2015, 10, e0144445. [CrossRef] [PubMed]

21. Environmental Law \& Policy Center. An Assessment of the Impacts of Climate Change on the Great Lakes; Environmental Law \& Policy Center: Chicago, IL, USA, 2019.

22. Penney, J.; Behan, K.; Pinto, E.; Rodgers, C.; Weigeldt, N. Protecting Your Community from Climate Change; Clean Air Partnership: Toronto, ON, Canada, 2012.

23. McDermid, J.L.; Dickin, S.K.; Winsborough, C.L.; Switzman, H.; Barr, S.; Gleeson, J.A.; Krantzberg, G.; Gray, P.A. State of Climate Change Science in the Great Lakes Basin: A Focus on Climatological, Hydrologic and Ecological Effects; Prepared Jointly by the Ontario Climate Consortium and Ontario Ministry of Natural Resources and Forestry to Advise Annex 9—Climate Change Impacts under the Great Lakes Water Quality Agreement; Ontario Climate Consortium: Toronto, ON, Canada, 2015.

24. Tricco, A.C.; Lillie, E.; Zarin, W.; O’Brien, K.; Colquhoun, H.; Kastner, M.; Levac, D.; Ng, C.; Sharpe, J.P.; Wilson, K.; et al. A Scoping Review on the Conduct and Reporting of Scoping Reviews. BMC Med. Res. Methodol. 2016, 16, 15. [CrossRef] [PubMed]

25. Bhattacharjee, K.; Behera, B. Does Forest Cover Help Prevent Flood Damage? Empirical Evidence from India. Glob. Environ. Chang. Hum. Policy Dimens. 2018, 53, 78-89. [CrossRef]

26. Espeland, E.K.; Kettenring, K.M. Strategic Plant Choices Can Alleviate Climate Change Impacts: A Review. J. Environ. Manag. 2018, 222, 316-324. [CrossRef]

27. Dedekorkut-Howes, A.; Torabi, E.; Howes, M. When the Tide Gets High: A Review of Adaptive Responses to Sea Level Rise and Coastal Flooding. J. Environ. Plan. Manag. 2020, 63, 2102-2143. [CrossRef]

28. Boesch, D.F. Scientific Requirements for Ecosystem-Based Management in the Restoration of Chesapeake Bay and Coastal Louisiana. Ecol. Eng. 2006, 26, 6-26. [CrossRef]

29. Burdon, F.J.; Ramberg, E.; Sargac, J.; Forio, M.A.E.; de Saeyer, N.; Mutinova, P.T.; Moe, T.F.; Pavelescu, M.O.; Dinu, V.; Cazacu, C.; et al. Assessing the Benefits of Forested Riparian Zones: A Qualitative Index of Riparian Integrity Is Positively Associated with Ecological Status in European Streams. Water 2020, 12, 1178. [CrossRef]

30. Carro, I.; Seijo, L.; Nagy, G.J.; Lagos, X.; Gutierrez, O. Building Capacity on Ecosystem-Based Adaptation Strategy to Cope with Extreme Events and Sea-Level Rise on the Uruguayan Coast. Int. J. Clim. Chang. Strateg. Manag. 2018, 10, 504-522. [CrossRef]

31. Weisner, E.; Schernewski, G. Adaptation to Climate Change: A Combined Coastal Protection and Re-Alignment Scheme in a Baltic Tourism Region. J. Coast. Res. 2013, 1963-1968. [CrossRef]

32. Spalding, M.D.; Ruffo, S.; Lacambra, C.; Meliane, I.; Hale, L.Z.; Shepard, C.C.; Beck, M.W. The Role of Ecosystems in Coastal Protection: Adapting to Climate Change and Coastal Hazards. Ocean Coast. Manag. 2014, 90, 50-57. [CrossRef]

33. Cooper, J.A.G.; Pile, J. The Adaptation-Resistance Spectrum: A Classification of Contemporary Adaptation Approaches to Climate-Related Coastal Change. Ocean Coast. Manag. 2014, 94, 90-98. [CrossRef]

34. Morris, R.; Strain, E.M.A.; Konlechner, T.M.; Fest, B.J.; Kennedy, D.M.; Arndt, S.K.; Swearer, S.E. Developing a Nature-Based Coastal Defence Strategy for Australia. Aust. J. Civ. Eng. 2019, 17, 167-176. [CrossRef]

35. Seavey, J.R.; Gilmer, B.; McGarigal, K.M. Effect of Sea-Level Rise on Piping Plover (Charadrius Melodus) Breeding Habitat. Biol. Conserv. 2011, 144, 393-401. [CrossRef]

36. Hunter, E.A.; Nibbelink, N.P.; Alexander, C.R.; Barrett, K.; Mengak, L.F.; Guy, R.K.; Moore, C.T.; Cooper, R.J. Coastal Vertebrate Exposure to Predicted Habitat Changes Due to Sea Level Rise. Environ. Manag. 2015, 56, 1528-1537. [CrossRef]

37. Hoggart, S.P.G.; Hanley, M.E.; Parker, D.J.; Simmonds, D.J.; Bilton, D.T.; Filipova-Marinova, M.; Franklin, E.L.; Kotsev, I.; Penning-Rowsell, E.C.; Rundle, S.D.; et al. The Consequences of Doing Nothing: The Effects of Seawater Flooding on Coastal Zones. Coast. Eng. 2014, 87, 169-182. [CrossRef]

38. Bilkovic, D.M.; Mitchell, M.; Mason, P.; Duhring, K. The Role of Living Shorelines as Estuarine Habitat Conservation Strategies. Coast. Manag. 2016, 44,161-174. [CrossRef]

39. Carus, J.; Paul, M.; Schroeder, B. Vegetation as Self-Adaptive Coastal Protection: Reduction of Current Velocity and Morphologic Plasticity of a Brackish Marsh Pioneer. Ecol. Evol. 2016, 6, 1579-1589. [CrossRef] [PubMed]

40. Moller, I. Applying Uncertain Science to Nature-Based Coastal Protection: Lessons From Shallow Wetland-Dominated Shores. Front. Environ. Sci. 2019, 7, 49. [CrossRef]

41. Thia-Eng, C. Essential Elements of Integrated Coastal Zone Management. Ocean Coast. Manag. 1993, 21, 81-108. [CrossRef]

42. Mycoo, M.; Chadwick, A. Adaptation to Climate Change: The Coastal Zone of Barbados. Proc. Inst. Civ. Eng. Marit. Eng. 2012, 165, 159-168. [CrossRef]

43. Marijnissen, R.; Esselink, P.; Kok, M.; Kroeze, C.; van Loon-Steensma, J.M. How Natural Processes Contribute to Flood ProtectionA Sustainable Adaptation Scheme for a Wide Green Dike. Sci. Total Environ. 2020, 739, 139698. [CrossRef]

44. Audubon. Coastal Resilience. 2020. Available online: https://www.audubon.org/conservation/coastal-resilience (accessed on 9 November 2020). 
45. Cialdea, D.; Mastronardi, L. Integrated Approach in the Planning Stage for Landscape Conservation in the Coastal Italian Areas. Int. J. Des. Nat. Ecodyn. 2014, 9, 296-306. [CrossRef]

46. Burger, J.; O’Neill, K.M.; Handel, S.N.; Hensold, B.; Ford, G. The Shore Is Wider than the Beach: Ecological Planning Solutions to Sea Level Rise for the Jersey Shore, USA. Landsc. Urban Plan. 2017, 157, 512-522. [CrossRef]

47. Devitt, K.; Bradley, D. Coastal Waterbirds Are in Decline, 8th ed.; Marine Birds: Victoria, BC, Canada, 2018 ; pp. 76-83.

48. Niagara Peninsula Conservation Authority. Forestry; Niagara Peninsula Conservation Authority: Welland, ON, Canada, 2021.

49. University of Waterloo. Building Community Resilience through Planned Retreat Canadian Coastal Resilience; University of Waterloo: Waterloo, ON, Canada, 2020. 